\title{
Cost Overruns of Public Sector Construction Projects: A Developing Country Perspective
}

\author{
Richard Ohene Asiedu \\ Graduate School of Business \\ Ghana Institute of Management and Public Administration \\ Accra, Ghana \\ Ebenezer Adaku ${ }^{1}$ \\ Graduate School of Business \\ Ghana Institute of Management and Public Administration \\ Accra, Ghana
}

Please cite this article as: Asiedu, R.O. and Adaku, E. (2019), "Cost overruns of public sector construction projects: a developing country perspective", International Journal of Managing Projects in Business, Vol. 13 No. 1, pp. 66-84. https://doi.org/10.1108/IJMPB-09-2018-0177

\footnotetext{
${ }^{1}$ Corresponding author: E. Adaku
}

E-mail: eadaku@gimpa.edu.gh 


\title{
Cost Overruns of Public Sector Construction Projects: A Developing Country Perspective
}

\begin{abstract}
Purpose - Cost overrun of construction projects has been a key concern for all stakeholders of projects for many decades now. Many studies have been done in the past and continue to be done currently to understand the underlying causes of construction project cost overruns. However, the empirical evidence of the causes seem not be clear due to the silo approach in understanding the causes of construction project cost overruns. This study seeks to take the debate a step forward by providing an understanding of the causes of project cost overrun from a system's perspective, especially from a less researched environment.

Design/methodology/approach - Data was collected and analysed from 131 respondents who were mainly involved in construction works in public procurement entities in Ghana. A twostaged approach was employed in collecting data from the respondents. The first stage involved an interview session with key informants in the construction industry in Ghana to ascertain the detailed causes of cost overrun of construction projects. The second stage focused on the validation of these detailed factors by a wider stakeholder group through questionnaires. Factor analysis was employed to consolidate these detailed factors into major causes of construction project cost overruns.
\end{abstract}

Findings - The results show that there are primarily four (4) major causes of most public sector construction projects cost overruns. These four major causes of cost overruns are poor contract planning and supervision; change orders; weak institutional and economic environment of projects and lack of effective coordination among the contracting parties.

Originality/value - The study provides more insights as to the critical and major factors that underpin public sector construction projects cost overruns and more importantly provides a basis for common treatment of the multiple risk factors engendering public sector construction projects cost overruns.

Keywords: Public Sector, Project Cost Management, Construction projects, Exploratory Factor Analysis (EFA), Developing Countries

Paper type: Research paper 


\section{Introduction}

Most developing countries have been experiencing economic growth over the last decades. For instance, Ghana, a developing country in Sub Saharan Africa has been experiencing a Gross Domestic Product (GDP) growth of about 7\%, on the average, between 2010 and 2017 (Ghana Statistical Service, 2018). The construction industry remains a very important industry for developing countries as the industry is responsible for providing critical infrastructure for major economic and social developments in these countries. As a result, the contribution of the construction industry to the GDP of most developing countries is relatively significant. For example, in Ghana, the contribution of the construction industry to the overall GDP between 2010 and 2017 has been about 12\% on the average (Ghana Statistical Service, 2018). Therefore, since most developing countries spend relatively significant portions of their GDPs on construction projects in the construction industry, it is important that the performance of projects in the industry is paid attention to in order to ensure efficient use of the tax payer's money. Especially, in developing countries where there are fiscal challenges, this call becomes even more urgent. Similar to other industries, the construction industry has key measures of performance. One of such performance measures, especially for projects in the industry, is cost. This is because every client or construction project sponsor would like to have the construction project completed within a specified or agreed upon budget. Cost is one of three key performance criteria in the project management literature. Apart from cost, other performance criteria for projects are time and quality. These performance criteria (cost, time and quality) are referred to as the iron triangle (Atkinson, 1999). Generally, these performance criteria, consider the performance of the project, particularly, construction projects, in the immediate or short term. This is because, a project completing within or on budget, on time and to the specified quality does not necessarily mean that it would meet the client or construction project sponsor's needs or satisfaction in the medium to long term. Clients or construction project sponsors may have other requirements or needs (in the medium to long term) for which the project is thought of. Other performance measures other than cost, time and quality may be necessary to measure the performance of the construction projects in such time zones (medium and long terms) other than the short or immediate term.

The cost criterion, however, has featured prominently in most definitions of project management performance, particularly success. For example, the UK Association of Project Management (APM) Body of Knowledge (BoK), other pioneer and recent authors (Wright, 1997; Turner, 1993; Morris and Hough, 1987; Wateridge, 1998; deWit, 1988; McCoy, 1987; 
Pinto and Slevin, 1988; Saarinen, 1990; Rosenfeld, 2014; Ahiaga-Dagbui et al., 2017; Ortiz et al., 2018) have all placed the cost criterion at the cutting edge of construction project success. Even though the definition of project success has been expanded to include other factors, the cost factor remains central (Papke-Shields, 2010). Recognising project cost as major risk factor, the Project Management Institute's (PMI) has included project cost management as one of the ten knowledge areas every project manager must master (PMI, 2000).

Despite its recognition by project managers as critical to project success over half a century now, construction projects continue to suffer budget overruns to date. Consequently, researchers have made several attempts to diagnose the causes of the perennial cost overruns in a bid to find a sustainable antidote to the risks associated with it (see Flyvbjerg et al. 2002; Flyvbjerg, 2009; Jennings, 2012; Lovallo and Kahneman, 2003; Love et al., 2012; Okmen and Öztas, 2010; Skitmore and Ng, 2003; Rahman et al., 2013; Vu et al., 2016; Ullah et al., 2018). For example, Flyvbjerg et al (2003) reported that 258 projects representing $90 \%$ of roads and rail projects in 20 countries experienced cost overruns. The authors indicated that while roads projects suffered an average of $20 \%$, rail projects encountered an average of $45 \%$ budget excesses and, therefore, concluded that the risk of construction cost overrun has not reduced over the past 70 years, despite the debate on its causes and potential solutions in literature and practice. Ameyaw and Oteng-Seifah (2010) report an average of 23\% cost overrun of 62 building projects surveyed in Ghana. Asiedu and Alfen (2014) reported similar findings with $72 \%$ out of 321 public building projects recording cost overruns in Ghana. Beside the abundance of evidence regarding the incidence of cost overruns, there is no consensus among researchers and practitioners on the causes of this undesirable global phenomenon. The triggers of this risk appear to be numerous, dynamic and country as well as sector specific. Even though several studies have attempted to identify the causes of cost overruns in different countries, previous authors have sought to treat the factors in silos with little emphasis on the interrelationships amongst the factors. The purpose of this study is therefore to identify how the individual and detailed factors that engender cost overruns in public sector construction projects in developing countries interrelate. In other words, this study seeks to explore, if there are some unobserved or latent variables underneath the myriad and detailed factors that engender cost overruns in public sector construction projects in developing countries. The identification of such interrelationships between the detailed causative cost overrun factors or latent variables will provide an easy and effective basis for proffering common treatments or solutions to the related causative factors. 
The study, generally, is structured into six sections. The first section deals with the introduction where the motivation for this study is presented. The second section provides a literature review on construction project cost overruns. The third section deals with the methodology for the study. In the fourth section, the results of the analysis are presented. The fifth section considers the discussions of the study results and finally the sixth section provides conclusions to the study, points out the limitations of the study and indicates pointers for future research on the phenomenon under consideration.

\section{Literature Review}

\subsection{Incidence of Cost Overruns}

A lot of factors have been considered to cause construction projects cost overruns in construction project management literature. Ahiaga-Dagbui and Smith (2014) classifies the sources of cost overruns over a continuum of attributes such as risk and uncertainties (Skitmore and Ng, 2003; Okmen and Öztas, 2010), strategic misrepresentation and optimism bias (Flyvbjerg et al. 2002; Lovallo and Kahneman, 2003; Jennings, 2012), scope creep (Love et al., 2012), and suspicious foul play and corruption (Wachs, 1990; Flyvbjerg, 2009).

The construction industry is arguably one of the most challenging, dynamic and risky industries (Mills, 2001). The industry is often exposed to all manner of risks such as changes in scope of works, financial distress and cash flow challenges, unstable ground conditions as well as materials and labour shortages with cost and time ramifications. Generally, the industry has a poor reputation for managing risk which has resulted in many projects failing to meet their cost targets (Raftery, 1994; Mills, 2001; Matta \& Ashkenas, 2003; Flyvbjerg et al., 2004; Evans, 2005; Enshassi \& Ayyash, 2014; Kim et al., 2018). Tah and Carr (2000), differentiates between risk and risk factors. According to Tar and Carr, risk factors do not directly affect project activities but do so through risk. The distinction drawn between the two leads to the assumption that risks are triggered by risk factors. An effective evaluation of the risks involved in construction projects is a significant requirement for managing construction projects successfully. Such a risk evaluation will lay a sound foundation for proffering appropriate risk mitigation measures and actions for effective management of construction projects (Paek et al., 1993). Molenaar (2005) identify three forms of risks that confront a project - known/knowns 
(known and quantifiable), the known/unknowns (known but unquantifiable) and the unknown/unknowns (unrecognised risk). Cooper and Chapman (1987) classify risks into two major forms - primary and secondary risks according to their nature and magnitude. Tar and Carr (2000) categorised risks into internal and external risk factors.

Some researchers have identified more unsuspecting sources of construction projects cost overruns. A study by Flyvbjerg (2008) identifies three possible reasons behind cost overruns: “technical explanations" (Flyvbjerg, 2002; 2005) "political-economic explanations (Flyvbjerg, 2002) and "psychological explanations" (Flyvbjerg, 2007). Technical explanations are the commonest reasons behind overruns (Flyvbjerg, 2009) and have gained much more credence amongst estimators and project managers (Flyvbjerg 2002; 2005). Technical explanations are linked to lack of experience on the part of estimators, imperfect forecasting techniques, honest mistakes, inherent problems in predicting the future and inadequate data, etc. (Flyvbjerg 2002; 2005). Flyvbjerg et al. (2002; 2005) and Wachs (1990) also associate overruns in large infrastructure projects to political-economic and psychological explanations. The political explanations suggest that project planners and sponsors during forecasting strategically and deliberately overestimate benefits and underestimate cost in order to maximize the chances of the project getting funded. The psychological explanations accounts for inaccuracies in estimation traced from what the psychologists refer to as optimism bias and planning fallacy (Kahneman and Tversky, 1979; Kahneman and Lovallo, 1993; Lovallo and Kahneman, 2003). Optimism bias is described as the cognitive predisposition to evaluate future events in a more positive light than they actually are in reality (Lovallo and Kahneman, 2003). The concept of planning fallacy describes the situation where decision makers decide based on delusional optimism instead of rational weighting of gains, losses and probabilities by overestimating benefits and underestimating costs (Flyvbjerg, 2009). Meanwhile, unlike strategic misrepresentation, the concept of optimism bias cannot be equated to strategic misrepresentation because it does not evolve from deceptive intent.

Essentially, the three main causes of construction projects cost overruns (technical explanations, political-economic explanations and psychological explanations) as indicated by Flyvbjerg (2008) reinforce the "double-void contexts" in respect of the institutional and economic environments in most developing countries in which projects take place (Ofori- 
Dankwa \& Julian, 2011). In most developing countries, there exist institutional and resource voids. The institutional voids are reflected in the absence of market-supporting institutions, specialized intermediaries and contract-enforcing mechanism (Khanna and Palepu, 2006), while the resource voids represent the lack of appropriate human resources, financial resources and other relevant capabilities. Both voids are deemed to play critical roles in cost overruns of construction projects in developing countries contexts. For instance, where very competent and strong institutions exist, the challenge of "political-economic" and "psychological explanations" to construction projects cost overruns could be held in check or moderated appropriately. Again, the development and availability of appropriate human resources can deal with the "technical explanations" associated with cost overruns.

\subsection{Beyond Delusional and Deceptive Factors}

Davies et al. (2014) has emphasised that, an effective risk management approach can provide a framework to identify and assess potential risks so that response actions can be taken to mitigate them. According to Love et al. (2009; 2012), whereas the reasons proffered by Flyvbjerg et al. (2005) contributed to ameliorating the understanding as to why economic infrastructure projects experience cost overruns, further investigations are required. While the studies by Love et al. (2009), looked at social infrastructure projects such as schools, hospitals and museums with cost below A $\$ 33$ million, the studies carried out by Flyvbjerg focused on mega projects defined as projects that cost in excess of US\$ 1 billion (Flyvbjerg et al., 2003). Love et al. posit that albeit optimism bias and misrepresentation could be potential reasons behind overruns in large public funded infrastructure projects, these reasons cannot be generalised for all projects within the construction industry. According to Ahsan and Gunawan (2009), the soft and often intangible objectives of basic social infrastructure projects developed to meet the basic living standards of the citizenry raises unique challenges. One major underlying reason is that unlike the smaller projects, mega projects tend to receive a lot of media attention and public furore throughout the entire development process because the community often contribute to their funding (Love et al., 2012; Masrom et al., 2015).

Love et al. (2009) argue that an appreciable amount of projects end up with overruns outside the effects of delusions (optimism bias) and deception (strategic misrepresentation). Hence to attribute all overruns to just optimism bias and strategic misrepresentation is not only overly 
simplistic but also misleading especially considering the multifaceted web of variables and conditions that interact with one another during the procurement process (Love et al., 2012). The rebuttal from Love et al. (2012) therefore suggests a shift in focus away from deception and delusions and a consideration of the intermediary events and actions that contribute to cost overruns. They posit that the underlying factors that are resident within the environment within which social infrastructure projects are procured act in congruence to destabilize the functioning and management of the project. This position taken by Love et al. debunks the explanation of foul play as suggested by Wachs (1990) and Flyvbjerg (2009) and rather point to the events that take place at the pre-contract and post-contract stages of construction. This position is largely shared by Ahsan and Gunawan (2009), Creedy et al. (2010) and Odeck (2004). Both the internal and external environments of construction projects are dynamic and relatively uncertain and hence the changes that occur during a project's development may have major and normally unpredictable effects on its organisation and management (Love, Wang, \& Tiong, 2013). With cost overrun as a global phenomenon, there are bound to be different factors competing for dominancy depending on several factors which include geographical location, level of development, client type, size of project, the culture of the people, etc. However, many of the risk management approaches developed by contractors and their consultants are not dynamic enough to analyse and assess risks (Too and Too, 2010). As a result, communicating construction project risks become poor, incomplete, and inconsistent throughout the construction supply chain.

\section{Research Method}

A preliminary interview of eighteen (18) experts in the Ghanaian Construction Industry was conducted which resulted in the identification of twenty two (22) detailed factors that engender cost overruns. The purpose of the interviews was to understand and solicit from these key experts the underlying causes of cost overruns of construction projects in the public sector after Adaku et al. (2018). During the interviews, understanding and prior knowledge of the causes of cost overruns in construction projects from previous studies were also discussed and shared with the experts to verify their validity in the Ghanaian construction project environment. These experts comprised professionals in the Ghanaian Construction Industry and academics who research into the built environment. These twenty two (22) detailed factors formed the basis of the design of closed ended questionnaires targeting practitioners of construction within the public sector. According to Chan (1998), the response rate of a survey questionnaire is a 
function of the layout and its physical attractiveness. The structure and language of the survey questionnaire was therefore guided by considerations of appeal from respondents, ease of reading and understanding by both technical and non-technical respondents.

Gill and Johnson (2010) indicate that piloting is necessary because it is difficult to predict how respondents will interpret and react to the questions. An initial draft of the questionnaires was therefore pre-tested with 15 construction professionals from industry and academia comprising 5 architects, 5 engineers and 5 quantity surveyors in order to check for clarity and verify completeness of the questions in capturing the relevant factors. The necessary feedback received after the pre-testing was assessed and then considered where necessary, thus ensuring the questionnaire addressed the core issues of the research.

Owing to the absence of a comprehensive list of contractors, poor addressing system from which an accurate sampling frame could be developed and anticipated difficulty in gaining the support of potential respondents, a purposive sampling technique was adopted in administering 240 questionnaires. Respondents were requested to rate the factors based on a Likert scale of one(1) indicating not critical and five(5) indicating extremely critical. Personal delivery method, which has been confirmed to yield a higher return rate, was adopted in administering the questionnaires. Ten (10) per cent stamped questionnaires (based on the response rate) were administered again to respondents who had previously fully completed and submitted their questionnaire to check for consistency and reliability of the earlier responses.

\subsection{Factor Analysis}

Factor analysis was employed to uncover the interrelationships that exist among the large number of variables in order to establish which of the variables could be measuring aspects of the same phenomenon that were thought of as contributing to cost overruns.

Debate amongst statisticians continues about the adequate sample size permissible for undertaking factor analysis and has resulted in several rules of thumb (Field, 2013). For instance, O'Rourke et al. (2005) recommend sample sizes of at least 100 or 5 times the number of variables to be included in the principal component analysis. Meanwhile, according to Guadagnoli and Velicer (1988), contrary to the popular rules, sample size as a function of the number of variables is not an important factor in determining stability but rather component saturation and absolute sample size. However, Field (2013) indicates that the most significant factor in determining the adequacy of factor solution is not only the absolute sample size but 
the absolute magnitude of the factor loadings as well. Hence, Guadagnoli and Velicer (1988) suggest that, if a factor has four or more loadings greater than 0.6 , then it is adequate for factor analysis regardless of the sample size. The factor analysis technique was used to reduce the twenty two (22) detailed factors to a smaller number of unobserved or latent factors that engender cost overruns of public sector construction projects. Principal components analysis was employed to identify the unobserved or latent factors because of its ease and superior capability for data-reduction for extraction. Principal factor extraction with Promax rotation and Kaiser normalisation was performed with the use of the SPSS Factor tool on the twenty two (22) detailed factors, causing cost overruns of public sector construction projects, from the 131 responses out of the 240 questionnaires administered.

Table 2 indicates the percentage of variance and the cumulative percentage of variance. Concerning factor rotation, two approaches are usually considered. That is the oblique and the orthogonal approaches. An orthogonal rotation approach, including varimax, equamax, quartimax, among others, constrains factors to be independent of each other, while an oblique rotation approach, including promax, oblimin, quartimin, among others, allows factors to be correlated. Generally, the results of an orthogonal rotation approach are usually more complex than the results of an oblique rotation and can sometimes mislead with the presence of significant correlations among factors (See Fabrigar et al., 1999). Besides, many constructs in scientific studies are mostly not deemed to be independent of each other, hence the oblique rotation approach would be deemed fit to obtain several theoretically acceptable factors (Hair et al., 1998). Promax as an oblique rotation approach has been employed by a number of studies (Lam et al., 2008; Kärnä et al., 2009; Chan and Lee, 2009). Therefore, Promax rotation approach was eventually used by this study.

In addition, the Kaiser-Meyer-Olkin (KMO) test is one of the tests required to examine the appropriateness of factor analysis for the factor extraction. The Kaiser-Meyer-Olkin (KMO) measure of sampling adequacy which compares the observed correlation coefficients to the partial correlation coefficients can also be used to assess the adequacy of a sample size. The KMO statistics varies between 0 and 1 and according to Field (2013), a KMO value greater than 0.50 is acceptable to develop a successful factor analysis. The sample size of 131 and KMO of sampling adequacy of 0.85 was thus considered adequate. 
The process of factor analysis can be categorised into two stages - factor extraction and factor rotation (Norusis, 1993). The main goal of factor extraction is to elicit the factors through principal components analysis. According to Suhr (2006), arriving at the number of factors to extract in a factor analysis implies retaining the factors that account for the most variance in the data. Two criteria were considered for factor extraction in this research: the Kaiser's criterion which considers factors with an eigenvalue greater than one, Cattell's scree test which shows the point at which the eigenvalues begin to level off in a plot of eigenvalue against the number of factors as indicated in Figure 1.

\section{Data Presentation}

\subsection{General Profile of Respondents}

Background knowledge about the respondents to a survey of this nature helps to assess the reliability and integrity of the data received in order to generate confidence and credibility in the results (Tavakol and Dennick, 2011). A return rate of almost 55\% (131 out of 240) was achieved in the survey comprising $33.6 \%$ clients, $22.1 \%$ contractors and $44.3 \%$ consultants. This relatively good response rate can be attributed to the strict adherence to the strategies adopted in administering and retrieving the questionnaires and possibly due to the high interest displayed by the respondents in the research. Additionally, all the confirmatory questionnaires (15) were returned. A comparison of the results between the original and the confirmatory questionnaires revealed $77 \%$ of the responses were similar to the ratings offered during the main survey. The information offered by the respondents was therefore considered consistent, reliable and valid. Table 1 shows the profile of the respondents that responded to the survey on behalf of their companies and institutions.

[Table 1 about here]

Table 1 shows that a little over $80 \%$ of the respondents had more than 5 years. Experience is a very important factor to consider in survey analysis, as it could always be a key cause of differing perceptions amongst the respondents. A greater share of the respondents had bachelor's degree (40.5\%) and masters' degree (37.4\%). This rich educational background of 
the respondents coupled with the level of experience of the respondents is an indication that the respondents had the capacity to respond to the survey, hence enhancing the credibility of the responses. Table 2 shows that the first four components demonstrated eigenvalues greater than one $(13.49,1.87,1.12$ and 1.04) and considered very encouraging based on the eigenvalueone criterion because the next eigenvalue of 0.89 cannot be considered as a "near-miss". The Table 2 further shows that the first four components account for approximately $80 \%$ of the total variance which implies that according to the "percentage of variance accounted for" criterion, the four components retained are appropriate.

[Table 2 about here]

A careful study of the scree plot in Figure 1 also reveals several breaks within the data between components 1 and 4 after which it begins to flatten out beginning with component 5 .

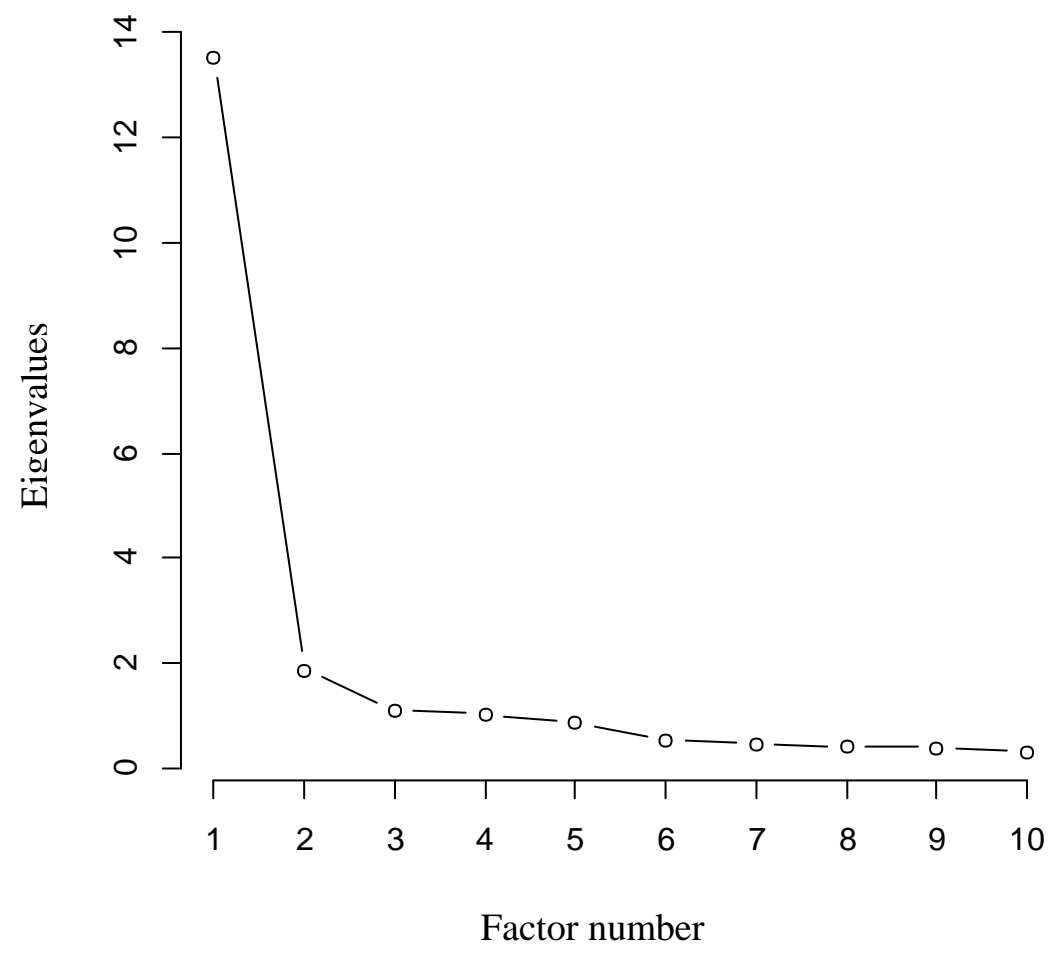

Figure1: Scree plot

The goal of factor rotation on the other hand is to make the factors more interpretable. In order to get factor loadings that are easy to interpret, a varimax rotation was conducted to preserve the orthogonality of the principal components and to reduce the number of factors on which 
the variables have high loadings. Kaming et al. (2010) defines factor loadings as simply the correlation between an original variable/determinant and an extracted factor and hence the higher the absolute value of the factor loading, the more the variable contributes to that factor. Table 3 displays the results of the rotated factor pattern.

[Table 3 about here]

\section{Discussion}

\subsection{Factor One: Poor contract planning and supervision}

Factor one shows the seven variables that were extracted according to the rotated factor pattern account for $61.33 \%$ of the reasons behind cost overruns. A careful assessment of these seven variables reveals the pervasiveness of poor contract planning and supervision in respect of public sector construction projects.

Effective contract planning and supervision within the construction industry in the public sector in Ghana could still be said to be in its formative stages. Dansoh (2005) observes that there is hardly any long term strategic planning within the public sector. Small contracts and ad hoc approaches are favoured over fully-fledged economic sized tenders (Anvuur et al., 2006). Poor planning and supervision which has equally been identified by Ahadzie (1995) as a Critical Failure Factor (CFF) of construction projects within the GCI significantly reveals the technical incompetence of the project team with regards to the clear understanding of scope of works, project schedule management, realistic cost forecasting and estimation and baseline planning for effective controlling and monitoring over the project execution period. An appropriate reporting and feedback process is essential in ensuring an effective project monitoring and controlling. However, in most public sector construction projects in Ghana, there is lack of effective monitoring and controlling mechanisms in place leading to failures (particularly cost) of such projects. Doloi (2013) has observed that the lack of frequent and effective supervision and communication by consultants to relevant project stakeholders for timely remedial actions to be taken explain contractors' inability to keep up with projects performance targets. About 
$80 \%$ of the consultants in Ghana have their offices located in the capital city, Accra. Meanwhile most of the public sector construction projects are located across the country and very remote from the capital city, Accra (Amoah et al., 2011). This situation undermines the effective monitoring and controlling of the public sector construction projects by the consultants. Besides, extreme competition amongst consultants in the Ghanaian Construction Industry (GCI) forces most professionals to accept unrealistically low fees. Research according to Love et al. (2010) has proven that a key factor contributing to poor project planning and documentation, sub-optimal designs and supervision is the level of fees paid to consultancy firms. Effective construction project planning and supervision involve identifying activities and resources (on the part of the consultants) required to ensure the performance targets of the projects are achieved. However, the low levels of fees charged by the consultants usually undermine the effectiveness of the supervision. Again, the poor contract and project planning processes delay the project tendering processes and eventually lead to project cost overruns, especially in a project environment where the macroeconomic indicators are unstable and inflation is very volatile. The poor contract and project planning processes can be partly explained by political expediency and corruption among the public project implementing agencies. As a result, several projects are rushed and awarded before the financing arrangement and final budget approval.

According to Frimpong et al. (2003) and Al-Momani (2000), harsh weather conditions reduce productivity and delays the progress of works. The temperature in Ghana during the dry season can fluctuate between $30-38{ }^{\circ} \mathrm{C}$ with high humidity levels ranging between $25 \%$ to $80 \%$ eventually reducing labour productivity. Frimpong et al. (2003) and Okpala (1986) indicate that the high temperature and humidity levels generate body heat that causes workers to feel dull and uncomfortable which leads to stress. Unfortunately, most of the consultants and contractors on public sector construction projects in Ghana are unable to account for the cost of the harsh weather conditions during the contract and project planning phase. This leads to underestimation of the project costs and serves as a risk factor for construction project cost overruns. Again, under this factor, several projects are executed without much economic justification but championed through optimism bias or deliberate underestimation or incomplete design (see for instance, Flyvbjerg et al., 2002; Wells, 2013). All of these developments pose risks for construction projects cost overruns. 


\subsection{Factor Two: Change orders}

The second factor which extracted five variables is described as change orders and is associated with contract alterations such as additions, deletions or modifications. The factor explains a total of $8.54 \%$ of the total variance and has traditionally been considered as one of the major reasons behind cost overruns. Changes in the design protocols and processes can engender bespoke problems (Love et al., 2011). According to Rowland (1981), change orders is an "indication that something on a construction project has not gone as planned" and may result in either additional cost or time or both. Change orders issued to correct or modify the original design or scope of work during construction is inevitable for most projects (Alnuaimi et al., 2009). The FIDIC condition of contract indicates that "no variation can vitiate a contract'. However the client's right to initiate a change order is compensated by the contractor's right to an equitable adjustment in the contract price and duration.

The quality of a design is a function of the degree of consultancy services required, the method of selecting consultants and how fees are negotiated (Love et al., 2011). Errors and discrepancies in design and changes on the project during the implementation are suggestive of shortcomings and lack of due diligence during the planning and development stage of the project (Asiedu and Alfen, 2015). Unfortunately most projects commence hastily because of political expediency while some contracts by their arrangements may not permit pre-contract site visit for feasibility studies because a single design is meant to be repeated across the country. This phenomenon encourages the excessive use of prime cost and provisional sums which enhances the chances of collusion between consultants/public officials and contractors. Collusion according to Wells (2013) festers because contractors are eager to recover potential losses or money spent on bribes. Bordat et al. (2004) suggest the implementation of a change order management as a means to address change orders even though in the view of Alsuliman et al. (2012) change order management is still not fully understood. The prevalence of several "no-recorded-reason" for change orders usually leads to construction project scope creep and subsequently cost overruns.

\subsection{Factor three: Weak institutional and economic environment of projects}

Five variables were extracted under factor three which account for $5.1 \%$ of the total variance. An assessment of these five variables reveals an inherent weak institutional and economic environment of projects. The weak institutional environment of projects represents the inadequate institutional capacity, particularly human resource, as well as the inefficiencies 
embedded in the processes of delivering public sector construction projects. The human capacity required to deliver successful public sector construction projects is not only deficient among the construction project contractors and consultants but also client representatives such as the procurement officers within the various public procurement entities. The success of a project depends, to some extent, on the technical competence of the project team (Aje, 2012; Larson and Gray, 2018). The fact that these three variables (poor budget estimation of project cost sent to Ministry of Finance (MoF) by implementing agencies, poor calibre of contractors reflected in the contractor's technical staff and deficiencies within the public procurement process) were loaded on the same factor emphasises the need to build the capacity of procurement officers (within the various public procurement entities) as well as contractors.

Section 59 of the Public Procurement Act (PPA) (Act 663 as amended: 2003) is explicit on the selection criteria of the contractor with lowest evaluated tender price which according to Wells (2013) conforms to the requirements by multilateral development banks. The over reliance on price as the key determining factor for selecting contractors and consultants (Love et al., 2010) which facilitates subjectivity, nepotism and corruption has also been identified as a major cause of most project delivery problems (Aje, 2012). This approach is risky, considering the fact that in the lean season when there are no jobs, contractors are more likely to offer lower tenders just to remain in business with the hope of raising additional claims or carrying out substandard works during the project execution to compensate for any possible loss due to the under-pricing of construction projects (Aje, 2012). Reports citing poor capacity of procurement officials have also been indicated (Ameyaw et al., 2010; Osei-Tutu et al., 2011). Section 21 of the Public Procurement Act (PPA), Act 663 as amended: 2003, requires officers to prepare a procurement plan to be submitted to the MoF for consideration into the budget which forms part of the basis for budgetary allocations for a fiscal year in the public sector. Underestimation of the preliminary project cost, at the public procurement entity level, leads to poor budgeting for construction projects and eventual cost overruns.

Eyiah and Cook (2003) and Anvuur et al. (2006) reveal a lengthy payment process beyond thirty steps within the GCI. Several public officers who are not technically qualified within the bureaucratic process are required to visit the site and certify the valuation prepared by the project consultants. According to Osei-Tutu et al. (2010), Interim Payment Certificates (IPCs) and letters emanating from the project consultant or contractor's office are deliberately delayed by middle or lower ranked public officials resulting in petty corruption. Corrupt public officials 
tend to disregard the order of submission of IPCs by contractors and rather use their position to honour payment to contractors who are able to pay more bribes (ibid).

Again, with the weak macroeconomic structures and indicators, most developing countries suffer from excessive increases in material and labour prices over project durations. The undesirable economic environment, in which projects are carried out, makes most public sector construction projects in developing countries vulnerable to cost overruns.

\subsection{Factor four: Lack of effective coordination among the contracting parties}

Five variables were extracted under factor four which in total explains $4.73 \%$ of the total variance. An assessment of these variables reveals the lack of effective coordination among the contracting parties during the design and execution stage. Communication gaps over the design phase between project consultants and the client can deny the project consultants of vital information, which can lead to underestimation of cost, and excessive change orders during the execution phase. According to Love et al. (2009), several professionals deliberately violate established conventions when put under pressure to produce documentation, albeit such practices are inappropriate.

The need for a comprehensive design brief, clients proposed cash flow outlook, clients financial contingency plans, specifications, contract type, the urgency of the project and expected completion date, among others, need to be thoroughly discussed and all ambiguities clarified before kick starting construction projects. Transparency is essential in fostering and enhancing a seamless coordination and integration amongst the project team. Errors and discrepancies in the contract document and lack of communication and coordination during the design stage between consultants and public procurement entities hinder contractors' performance and engender disputes leading to prolonged contract durations. According to Akinci and Fischer (1998), errors and discrepancies trigger variations which are a key source of cost overruns for both clients and contractors. Again, Wells (2013) indicates that contract variations undermine the accuracy and certainty with which construction project costs are estimated and thus provide an avenue for several negotiations and opportunistic tendencies by project parties, especially contractors. The proficiency of the consultants design efficiency depends also to a large extent on the consistency of the clients design brief and hence the need for the establishment of a clear 
communication protocol. Communication barriers that engender estimating errors at the precontract stage according to Wells (2013) could result in the acceptance of unrealistically low tender prices which provides a basis for misinformation in respect of construction project funding decisions and arrangements. Protracted and intractable delays and uncertainties surrounding payment for work done on government projects according to Wells (2013) and Tuuli et al. (2007) weaken government's bargaining power and are major reasons why contracts are not enforced whiles lack of enforcement of contract provisions by all parties creates time at large scenarios. Payment delays often drives contractors to desperation, ruins their profitability, cripples their professional integrity and inhibits their zeal for doing a good work on time (United Nations Centre for Human Settlements [UNCHS], 1996). The need for the project consultant to offer early warning signs on delayed activities is as important as the client engaging the contractor on alternative measures about payment challenges before they occur. Government's reluctance to compensate contractors for payment delays makes it unjustifiable for consultants to also enforce Liquidated and Ascertained Damages (LADs) clauses in contracts in cases of delays.

Overdependence on imported construction materials either as finished products or raw materials often tends to delay progress of works and has been a major reason for price escalations. Ghana is largely a consuming economy and imports virtually about $80 \%$ of its construction inputs (Arku, 2009). Until recently, Ghana had only one cement manufacturing company that monopolised the whole construction industry and hence annual shut down of part of its production sections for routine and periodic maintenance works resulted in artificial scarcity and resulting in artificial price hikes due to panic buying. It is essential that the contractor is always in constant touch with its major suppliers to avert any surprises along the supply chain while any attempt to alter the design specification need to factor in the availability of the new material.

\section{Conclusions and limitations of the study}

The study sought to understand the reasons behind cost overruns of public sector projects in a less developed economy environment. This extends and contributes to the debate on the factors that engender cost overruns of projects in more developed economies and emerging economies. In achieving the study objective, data was collected and analysed from 131 respondents who were mainly involved in construction works in public procurement entities in Ghana. The factor 
analyses of the twenty two (22) detailed causes of cost overruns of public sector project projects in Ghana show that there are primarily four (4) major causes to why most public sector construction projects overrun in cost. These four major causes of cost overruns are poor contract planning and supervision (explaining about $61.33 \%$ of the reasons why public sector construction projects overrun in cost); change orders (explaining 8.54\% of cost overruns in public sector construction projects); weak institutional and economic environment of projects (explaining $5.10 \%$ of variance) and lack of effective coordination among the contracting parties (also explaining $4.73 \%$ of the variance).

Poor contract planning and supervision providing the most explanation for public sector projects cost overruns accentuates the problem of low accountability in the public sector systems in most developing countries or economies. To address this problem, it will be necessary to develop proper contract planning and supervision protocols for the public sector system. Again, in Ghana, adherence to these protocols by the public procurement entities should be demanded by bodies such as Public Procurement Authority (PPA) and the Audit Service. Such an accountability measure will streamline contract planning and supervision processes within public procurement entities and minimise the risks of project cost overruns. Besides, to address the phenomenon of poor contract planning and supervision which is underpinned by the problem of low accountability in the public sector, a national legislation which requires mandatory evaluations of public sector construction projects will be necessary. Such a legislation must, among others, focus on public sector construction project audits. The evaluation exercise will not only promote accountability in public sector construction projects but will also provide an opportunity for learning and improvement in the delivery of public sector construction projects. The national legislation must make National Development Planning Commission (NDPC) the anchor institution for the evaluations with technical support from the Public Procurement Authority (PPA) and Ministry of Works and Housing (MWH). Our finding of change orders corroborates the finding of Amoatey et al. (2015). They also found changes in designs as causes of delays and excessive cost in state housing projects in Ghana. We submit that when attention is paid to proper contract planning and supervision in the public sector through the development of effective contract planning and supervision protocols as well as a national legislation for public construction project evaluations, it will have positive effects on the project implementation in the form of reduced change orders and effective coordination between the contracting parties. Among the contract protocols should 
specifically be the development of a standardised project scope change request form to manage and alleviate the problem of change orders. The form, among other details, should capture the reason for the change request; the impact of the requested change as well as indicating the liability of the impact of the requested change. It is expected that some of these requirements by the form would discourage unnecessary changes to the scopes of public sector construction projects and minimise the risk of cost overruns. The Public Procurement Authority (PPA) could lead in such an effort. Again, the finding in respect of weak institutional and economic environment of projects would require that measures are put in place to build the capacities of public procurement entities as well as local contractors to effectively and efficiently deliver public sector construction projects. As part of the capacity building plan, PPA could engage professionals and academics in the construction industry to develop standardized curriculum or modules based on the deficiencies identified among project teams on public sector construction projects. The modules could be used to train and certify persons in both public procurement entities and contracting firms on project management and works procurement. Such certification documents by relevant team members of contracting firms could be made a requirement by PPA when submitting a tender by contracting firms. On the other hand, persons in public procurement entities involved in works procurement should be required by PPA to obtain such certifications.

Since the economic environments, in which projects are undertaken, affect the cost performance of public sector construction projects, it would be necessary for the government in Ghana and other developing countries to embark on conscious and concerted efforts to provide stable economic environments.

This study is not without limitations. First, the use of a purposive sampling approach instead of a random sample limits the generalisation ability of the findings of this study. Further studies should seek to use approaches that broaden the sample size to make the findings more generalizable. Second, the use of cross-sectional data limits the causal inferences capabilities in respect of the findings of this study. Hence, it is encouraged that future related studies are carried to provide better understanding and also to validate the findings of this study. Lastly, this study limited the survey to only three stakeholders of public sector construction projects clients, consultants and contractors. In the future, the survey should be broadened to include 
stakeholders such as materials suppliers, banks or financial institutions, etc to shed more light and validate the actual causes of cost overruns in public sector construction projects.

\section{References}

Adaku, E., Amoatey, C. T., Nornyibey, I., Famiyeh, S. and Asante-Darko, D. (2018), "Delays in new product introduction: Experiences of a food processing company in a developing economy", Journal of Manufacturing Technology Management, Vol. 29 No. 5, pp.811828.

Ahadzie, D. K. (1995), Factors affecting labour productivity in the construction industry in Ghana: The perception of consultants and contractors. Journal of the Building and Road Research Institute, Vol. 3 No 1, pp. 22-32.

Ahiaga-Dagbui, D. D. and Smith, S. D. (2014), "Rethinking construction cost overruns: cognition, learning and estimation”, Journal of Financial Management of Property and Construction, Vol. 19, No.1, pp.38-54.

Ahiaga-Dagbui, D. D., Love, P. E. D., Smith, S. D., and Ackermann, F. (2017), "Toward a Systemic View to Cost Overrun Causation in Infrastructure Projects: A Review and Implications for Research", Project Management Journal, Vol. 48 No. 2, pp. 88-98.

Ahsan, K. and Gunawan, I. (2010), “Analysis of cost and schedule performance of international development projects", International Journal of Project Management, Vol. 28 No. 1, pp. 68-78.

Aje, I. (2012), “The impact of contractors' prequalification on construction project delivery in Nigeria”, Engineering, Construction and Architectural Management, Vol. 19 No. 2, pp. 159-172.

Akinci, B. and Fischer, M. (1998), "Factors affecting contractors' risk of cost overburden", Journal of Management in Engineering, Vol.14 No. 1, pp. 67-76

Al-Momani, A. H. (2000), “Construction delay: a quantitative analysis". International journal of project management, Vol. 18 No. 1, pp. 51-59. 
Alnuaimi, A. S., Taha, R. A., Al Mohsin, M. and Al-Harthi, A. S. (2009), "Causes, effects, benefits, and remedies of change orders on public construction projects in Oman”, Journal of Construction Engineering and Management, Vol. 136 No. 5, pp. 615-622.

Alsuliman J., Bowles, G. and Chen, Z. (2012). Current practice of variation order management in the Saudi construction industry In: Smith, S.D (Ed) Procs 28th Annual ARCOM Conference, 3-5 September 2012, Edinburgh, UK, Association of Researchers in Construction Management, 1003-1012.

Ameyaw, C and Oteng Seifah, S. (2010), "Construction Project Delivery in Ghana - The performance of Traditional Procurement Method", West African Built Environment Research (WABER) Conference, University of Reading, 2010.

Ameyaw, C., Mensah, S. and Osei-Tutu, E. (2012), "Public procurement in Ghana: The implementation challenges to the public procurement law 2003 (Act 663)”. International Journal of Construction Supply Chain Management, Vol. 2 No. 2 , pp. 55-65.

Amoah, P., Ahadzie, D. K. and Dansoh, A. (2011), "The factors affecting construction performance in Ghana: the perspective of small-scale building contractors", The Ghana Surveyor, Vol. 4, No. 1, pp. 41-48.

Amoatey, C.T., Ameyaw, Y. A., Adaku, E. and Famiyeh, S. (2015), "Analysing delay causes and effects in Ghanaian state housing construction projects", International Journal of Managing Projects in Business, Vol. 8 No. 1, pp.198-214

Anvuur, A., Kumaraswamy, M. and Male, S. (2006), "Taking forward public procurement reforms in Ghana". CIB W107 Construction in Developing Countries International Symposium, Santiago, Chile

Arku, G. (2009), "Housing Policy Changes in Ghana in the 1990s: Policy Review”, Housing Studies, Vol. 24 No. 2, pp. 261-272.

Asiedu, R. O. and W Alfen, H. (2014). "Factors engendering cost misrepresentation of public sector projects in Ghana." International Journal of Sustainable Construction Engineering and Technology, Vol. 5 No. 2, pp. 13-24 
Association of Project Management [APM] (1995), Body of Knowledge (BoK) Revised in January 1995, Version 2.

Atkinson, R. (1999), "Project management: cost, time and quality, two best guesses and a phenomenon, it's time to accept other success criteria', International Journal of Project Management Vol. 17, No. 6, pp. 337-342.

Bordat, C., Labi, S., McCullouch, B. and Sinha, K.C. (2004), An analysis of cost overruns and time delays of INDOT projects. Technical Report Prepared for: INDOT-FHWA-JTRP.

Chan, E. H.W. and Lee, G. K. L. (2009), "Design considerations for environmental sustainability in high density development: a case study of Hong Kong”, Environment, Development and Sustainability, Vol.11 No. 2, 359-374.

Chan, W.M. (1998), Modelling construction durations for public housing projects in Hong Kong. PhD Thesis, University of Hong Kong.

Cooper, D. F. and Chapman, C. B. (1987). Risk analysis for large projects: models, methods, and cases. John Wiley \& Sons Inc.

Creedy, G. D. (2006). Risk factors leading to cost overrun in the delivery of highway construction projects (Doctoral dissertation, Queensland University of Technology).

Dansoh, A. (2005), "Strategic planning practice of construction firms in Ghana", Construction Management and Economics, Vol. 23 No. 2, pp. 163-168.

Doloi, H. (2013), "Cost overruns and failure in project management: understanding the roles of key stakeholders in construction projects', Journal of construction engineering and management, Vol. 139 No. 3, pp. 267-279.

Enshassi, A., and Ayyash, A. (2014), "Factors affecting cost contingency in the construction industry - Contractors' perspective", International Journal of Construction Management, Vol. 14 No. 3, pp. 215-239.

Evans, M. (2005), “Overdue and over budget, over and over again”. The Economist; Vol. 375 No. 8430, pp. 66. 
Eyiah, A. K. and Cook, P. (2003), "Financing small and medium-scale contractors in developing countries: A Ghana case study", Construction management and economics, Vol. 21 No. 4, pp. 357-367.

Fabrigar, L.R., Wegener, D. T., MacCallum, R. C. and Strahan, E.J. (1999). "Evaluating the use of exploratory factor analysis in psychological research", Psychological Methods, Vol. 4 No. 3, pp. 272-299.

Field, A. (2013). Discovering statistics using IBM SPSS statistics. Sage, London.

Flyvbjerg B., Bruzelius N. and Rothengatter W. (2003), Megaprojects and Risks: An Anatomy of Ambition, Cambridge University Press, Cambridge.

Flyvbjerg, B, Holm M.K.S, and Buhl, S.L. (2004), "What causes cost overrun in transport infrastructure projects?, Transport Review, Vol. 24 No 1, pp. 3-18.

Flyvbjerg, B. (2005), Policy and planning for large infrastructure projects: problems, causes, cures, Vol. 3781, World Bank Publications.

Flyvbjerg, B. (2009), "Survival of the unfittest: why the worst infrastructure gets built—and what we can do about it", Oxford review of economic policy, Vol. 25 No 3, pp. 344367.

Flyvbjerg, B., (2008), “Curbing Optimism Bias and Strategic Misrepresentation in Planning: Reference Class Forecasting in Practice", European Planning Studies, Vol 16, No 1, pp $3-21$.

Flyvbjerg, B., Holm, M. S. and Buhl, S. (2002). "Underestimating costs in public works projects: Error or lie?”, Journal of the American planning association, Vol. 68 No. 3, pp. 279-295.

Frimpong, Y., Oluwoye, J. and Crawford, L. (2003), "Causes of delay and cost overruns in construction of groundwater projects in developing countries; Ghana as a case study", International Journal of project management, Vol 21 No. 5, pp. 321-326.

Ghana Statistical Service (2018), "Provisional 2017 Annual Gross Domestic Product”, April 2018 Edition. Available at:

http://www.statsghana.gov.gh/docfiles/GDP/GDP2018/2017\%20Quarter\%204\%20an 
d\%20annual\%202017\%20GDP\%20publications/Annual_2017_GDP_April\%202018 \%20Edition.pdf (accessed August 27, 2018).

Gill, J. and Johnson, P. (2010), Research methods for managers, Sage Publications Ltd, London.

Guadagnoli, E., and Velicer, W. F. (1988), "Relation of Sample-Size to the Stability of Component Patterns", Psychological Bulletin, Vol. 103 No. 2, pp. 265-275.

O'Rourke, N., Hatcher, L. and Stepanski, E. J. (2005), A step-by-step approach to using the SAS system for univariate and multivariate statistics. Cary, NC: SAS Institute Inc.

Jennings, W. (2012), "Why costs overrun: risk, optimism and uncertainty in budgeting for the London 2012 Olympic Games”, Construction Management and Economics, Vol. 30 No. 6, pp. 455-462.

Kahneman, D. and Lovallo, D. (1993), "Timid choices and bold forecasts: A cognitive perspective on risk taking", Management science, Vol. 39 No. 1, pp. 17-31.

Kahneman, D. and Tversky, A. (1979), "Prospect theory: An analysis of decision under risk", Econometrica: Journal of the Econometric Society, Vol. 47 No. 2. pp. 263-292.

Kaming, P. F., Olomolaiye, P. O., Holt, G. D. and Harris, F. C. (1997), "Factors influencing construction time and cost overruns on high-rise projects in Indonesia", Construction Management \& Economics, Vol. 15 No. 1, pp. 83-94.

Kärnä, S., Junnonen, J. M. and Sorvala, V. M. (2009), "Modelling structure of customer satisfaction with construction", Journal of Facilities Management, Vol. 7 No. 2, pp. 111-127.

Khanna, T. and Palepu, K.G. (2006), "Emerging Giants: Building World-Class Companies in Developing Countries", Harvard Business Review, Vol. 84 No. 10, pp. 60-69

Kim, S.-Y.; Tuan, K. N.; Lee, J. D.; Pham, H. and Luu, V. T. (2018), "Cost overrun factor analysis for hospital projects in Vietnam", KSCE Journal of Civil Engineering, Vol. 22 No.1, pp. 1-11. 
Lam, E.W.M., Chan, A.P.C and Chan, D.W.M. (2008), "Determinants of Successful DesignBuild Projects", Journal of Construction Engineering and Management, Vol. 134 No.5, pp. 333-341.

Larson, E. W. and Gray, C. F. (2018), Project Management: The Managerial Process, McGraw-Hill Education, New York.

Lovallo, D. and Kahneman, D. (2003), "Delusions of success”, Harvard business review, Vol. 81 No.7, pp. 56-63.

Love, P. E., Edwards, D. J. and Irani, Z. (2012), "Moving beyond optimism bias and strategic misrepresentation: An explanation for social infrastructure project cost overruns", Engineering Management, IEEE Transactions on, Vol. 59 No. 4, pp. 560571.

Love, P. E., Edwards, D. J., Han, S. and Goh, Y. M. (2011), "Design error reduction: toward the effective utilization of building information modelling", Research in Engineering Design, Vol. 22 No.3, pp. 173-187.

Love, P. E., Edwards, D. J., Irani, Z. and Walker, D. H. (2009), "Project pathogens: The anatomy of omission errors in construction and resource engineering project”, Engineering Management, IEEE Transactions on, Vol 56 No. 3, pp. 425-435.

Love, P., Davis, P., Ellis, J. and On Cheung, S. (2010), "Dispute causation: identification of pathogenic influences in construction”, Engineering, Construction and Architectural Management, Vol.17 No.4, pp. 404-423.

Masrom, M. A. N., Rahim, M. H. I. A., Mohamed, S., Chen, G. K., and Yunus, R. (2015), "Successful criteria for large infrastructure projects in Malaysia", Procedia Engineering, Vol. 125, pp. 143-149.

Matta, F. and Ashkenas R. (2003), "Why good projects fail anyway”, Harvard Business Review, Vol. 81 No. 9, pp. 109-14.

McCoy F. A. (1987), Measuring Success: Establishing and Maintaining A Baseline, Project management Institute Seminar/Symposium Montreal Canada, Sep. 1987, pp. 47-52.

Mills, A. (2001) “A systematic approach to risk management for construction”, Structural survey, Vol. 19 No. 5, pp. 245-252. 
Molenaar, K. R. (2005), "Programmatic cost risk analysis for highway mega projects", Journal of Construction Engineering and Management, Vol. 131 No. 3, pp. 343-353.

Morris P.W.G and Hough G.H. (1987), "The Anatomy of Major Projects”, John Wiley, New York.

Norusis, M. (1993), SPSS for Windows Advanced Statistics, Release 6.0.

Odeck, J. (2004), "Cost overruns in road construction-what are their sizes and determinants?" Transport Policy, Vol. 11 No. 1, pp. 43-53.

Ofori-Dankwa, J. and Julian, S. D. (2011), “Utilizing an integrative multi-lens model to explain firm performance in emerging "double void" economies", International Studies in Management \& Organization, Vol. 41 No. 2, pp. 5 - 27.

Ökmen, Ö. and Öztaş, A. (2010), “Construction cost analysis under uncertainty with correlated cost risk analysis model”. Construction Management and Economics, Vol. $28 \quad$ No. 2, pp. 203-212.

Okpala, D. C. (1986), "Causes of delay and cost overrun in the construction industry", In CENSER Seminar series.

Ortiz, J. I., Pellicer, E., and Molenaar, K. R. (2018), "Management of time and cost contingencies in construction projects: a contractor perspective", Journal of Civil Engineering and Management, Vol. 24 No.3, pp. 254-264.

Osei-Tutu, E., Badu, E. and Owusu-Manu, D. (2010), Exploring corruption practices in public procurement of infrastructural projects in Ghana", International Journal of Managing Projects in Business, Vol. 3 No. 2, pp. 236-256.

Osei-Tutu, E., Mensah, S. and Ameyaw, C. (2011), The level of compliance with the public procurement Act (Act 663) in Ghana. In Management and Innovation for a Sustainable Built Environment MISBE 2011, Amsterdam, The Netherlands, June 20-23, 2011. CIB, Working Commissions W55, W65, W89, W112; ENHR and AESP.

Paek, J. H., Lee, Y. W., and Ock, J. H. (1993), "Pricing Construction Risk: Fuzzy Set Application." Journal of Construction Engineering and Management, ASCE, Vol. 119 No. 4, pp. 743-756. 
Papke-Shields, K.E., Beise, C., and Quan, J. (2010), "Do project managers practice what they preach, and does it matter to project success?" International Journal of Project Management, Vol. 28 No. 7, pp. 650-662.

Pinto, J. K. and Slevin, D. P. (1988), "Critical success factors across the project life cycle: definitions and measurement techniques", Project Management Journal, Vol. 19 No. 3, pp. 67-75.

Project Management Institute [PMI] (2000), "A guide to project management body of knowledge: PMBOK (Project Management Book of Knowledge) Guide”, $2^{\text {nd }}$ ed. Upper Darby, PA, USA.

R. O. Asiedu and H. W. Alfen (2015), "Understanding the underlying reasons behind time overruns of government building projects in Ghana," KSCE Journal of Civil Engineering, Vol. 20, No. 6, pp. 2103-2111

Raftery J. (1994), “Risk analysis in project management”. E and FN Spon: London.

Rahman, I.A., Memon, A.H. and Karim, A.T.A. (2013), "Significant Factors Causing Cost Overruns in Large Construction Projects in Malaysia", Journal of Applied Sciences, Vol. 13 No.2, pp. 286-293.

Rosenfeld, Y. (2014), "Root-cause analysis of construction-cost overruns", Journal of Construction Engineering Management, Vol. 40 No.1, retrieved from: https://ascelibrary.org/doi/10.1061/\%28ASCE\%29CO.1943-7862.0000789

Rowland (1981), "The causes and effects of change orders on the construction process", MS Thesis, Georgia Institute of Technology, Atlanta, GA.

Saarinen, T, (1990), "Systems development methodology and project success", Information and Management, Vol. 19 No. 3, pp. 183-193.

Skitmore, R. M. and Ng, S. T. (2003), "Forecast models for actual construction time and cost", Building and environment, Vol. 38 No. 8, pp. 1075-1083.

Suhr, D. D. (2006), Exploratory or confirmatory factor analysis?, SAS Institute Inc, Cary. 
Tah, J.H.M. and Carr, V. (2000), "Information modelling for a construction project risk management system", Engineering, Construction and Architectural Management, Vol. 7 No. 2, pp. 107-19.

Tavakol, M. and Dennick, R. (2011), "Making sense of Cronbach's alpha”, International Journal of Medical Education, Vol. 2, pp. 53-55.

Too, E. and Too, L. (2010), "Strategic infrastructure asset management: a conceptual framework to identify capabilities", Journal of Corporate Real Estate, Vol. 12 No. 3, pp. 196-208.

Turner J. R. (1993), “The Handbook of Project-based Management”, McGraw-Hill, London.

Tuuli, M. M., Baiden, B. K. and Badu, E. (2007), “Assessment and enforcement of liquidated damages in construction contracts in Ghana", Structural Survey, Vol. 25 No. 3/4, pp. 204-219.

Ullah, K., Abdullah, A. H., Nagapan, S., Sohu, S., and Khan, M. S. (2018), "Measures to Mitigate Causative Factors of Budget Overrun in Malaysian Building Projects", International Journal of Integrated Engineering, Vol. 10 No 9, pp. 66-71.

United Nations Centre for Human Settlements [UNCHS] (1996), "Policies and Measures for Small-Contractor Development in the Construction Industry”, United Nations Centre for Human Settlements, Nairobi.

Vu, H.A., Wang, J.Q., Min, L.X., Mai, S.H. and Nguyen, H.P. (2016), "Research on Cost Overrun Risk of Construction Phase of Vietnam Highway International Contracting Project”, Engineering, Vol. 8 No.3, pp. 86-98.

Wachs, M. (1990), "Ethics and advocacy in forecasting for public policy", Business and Professional Ethics Journal, Vol. 9 No. 1-2, pp. 141-57.

Wateridge, J. (1998), “How can IS/IT projects be measured for success?”, International Journal of project Management, 1998, Vol.16 No.1, pp. 59-63.

Wells, J. (2013), "Corruption and collusion in construction: a view from the industry", Corruption, Grabbing and Development: Real World Challenges, 23. 
Wright, J. N. (1997), “Time and budget: the twin imperatives of a project sponsor", International Journal of Project Management, Vol. 15 No. 3, pp. 181-186.

Table 1: Background Information of Respondents

\begin{tabular}{llllll}
\hline Description & Client & Contractors & Consultants & Total & $\begin{array}{c}\text { Prop } \\
(\%)\end{array}$ \\
\hline $\begin{array}{lllll}\text { Profession } \\
\text { Architects }\end{array}$ & 8 & 2 & 14 & 24 & 18.3 \\
Quantity surveyors & 19 & 12 & 32 & 63 & 48.1 \\
Engineers & 7 & 4 & 9 & 20 & 15.3 \\
Others & 10 & 11 & 3 & 24 & 18.3 \\
Experience (years) & & & & & \\
$0-5$ & 8 & 6 & 11 & 25 & 19.1 \\
$6-10$ & 24 & 14 & 30 & 68 & 51.9 \\
$10-20$ & 6 & 4 & 12 & 22 & 16.8 \\
$>20$ & 6 & 5 & 5 & 16 & 12.2
\end{tabular}

Education

\begin{tabular}{llllll} 
Technician/HND & 10 & 11 & 6 & 27 & 20.6 \\
Bachelor & 22 & 14 & 17 & 53 & 40.5 \\
Master & 12 & 4 & 33 & 49 & 37.4 \\
Doctorate & 0 & 0 & 2 & 2 & 1.5 \\
\hline
\end{tabular}


Table 2: Exploratory factor analysis of cost overrun causes

\begin{tabular}{|c|c|c|c|c|c|c|c|c|c|}
\hline \multicolumn{4}{|c|}{ Initial Eigenvalues } & \multicolumn{6}{|c|}{$\begin{array}{l}\text { Extraction Sum of Squared Rotation Sums of Squared } \\
\text { Loadings } \\
\text { Loadings }\end{array}$} \\
\hline Factors & Total & $\begin{array}{l}\% \\
\text { Variance }\end{array}$ & $\%$ & Total & $\begin{array}{l}\% \\
\text { Variance }\end{array}$ & $\begin{array}{l}\% \\
\text { Cumulative }\end{array}$ & Total & $\begin{array}{l}\% \\
\text { Variance }\end{array}$ & $\%$ \\
\hline 1 & 13.49 & 61.33 & 61.33 & 13.49 & 61.33 & 61.33 & 4.57 & 21.92 & 21.92 \\
\hline 2 & 1.87 & 8.54 & 69.88 & 1.87 & 08.54 & 69.88 & 4.49 & 21.53 & 43.45 \\
\hline 3 & 1.12 & 5.10 & 74.98 & 1.12 & 05.10 & 74.98 & 4.17 & 20.00 & 63.45 \\
\hline 4 & 1.04 & 4.73 & 79.71 & 1.04 & 04.73 & 79.71 & 3.39 & 16.26 & 79.71 \\
\hline 5 & 0.89 & 4.07 & 83.79 & & & & & & \\
\hline 6 & 0.54 & 2.50 & 86.28 & & & & & & \\
\hline 7 & 0.47 & 2.15 & 88.43 & & & & & & \\
\hline 8 & 0.43 & 1.97 & 90.40 & & & & & & \\
\hline 9 & 0.40 & 1.85 & 92.24 & & & & & & \\
\hline 10 & 0.32 & 1.49 & 93.74 & & & & & & \\
\hline 11 & 0.28 & 1.29 & 95.03 & & & & & & \\
\hline 12 & 0.23 & 1.05 & 96.08 & & & & & & \\
\hline 13 & 0.19 & 0.87 & 96.95 & & & & & & \\
\hline 14 & 0.16 & 0.75 & 97.70 & & & & & & \\
\hline 15 & 0.12 & 0.55 & 98.25 & & & & & & \\
\hline 16 & 0.10 & 0.44 & 98.69 & & & & & & \\
\hline 17 & 0.08 & 0.37 & 99.05 & & & & & & \\
\hline 18 & 0.07 & 0.33 & 99.38 & & & & & & \\
\hline 19 & 0.06 & 0.27 & 99.65 & & & & & & \\
\hline 20 & 0.03 & 0.13 & 99.79 & & & & & & \\
\hline 21 & 0.03 & 0.12 & 99.91 & & & & & & \\
\hline 22 & 0.02 & 0.09 & 100.00 & & & & & & \\
\hline
\end{tabular}


Table 3: Factor loading and total variance explained

\begin{tabular}{|c|c|c|c|c|c|c|}
\hline \multirow{2}{*}{ ID } & \multirow{2}{*}{ Variables } & \multicolumn{4}{|c|}{ Factor Loadings } & \multirow{2}{*}{$\begin{array}{l}\text { Variance } \\
\text { Explained }\end{array}$} \\
\hline & & F 1 & F 2 & F 3 & F 4 & \\
\hline $\mathrm{C} 1$ & $\begin{array}{l}\text { Lack of frequent and effective supervision by } \\
\text { consultants }\end{array}$ & 0.73 & & & & \multirow{7}{*}{61.33} \\
\hline $\mathrm{C} 10$ & $\begin{array}{l}\text { Implementing agencies awarding contracts even before } \\
\text { budget is approved by government }\end{array}$ & 0.67 & & & & \\
\hline $\mathrm{C} 13$ & Harsh weather conditions & 0.53 & & & & \\
\hline $\mathrm{C} 17$ & $\begin{array}{l}\text { Inexperience and mismanagement on the part of } \\
\text { consultants who handle government projects }\end{array}$ & 0.63 & & & & \\
\hline $\mathrm{C} 18$ & $\begin{array}{l}\text { Deliberate underestimation of initial project cost to } \\
\text { ensure projects are implemented }\end{array}$ & 0.83 & & & & \\
\hline $\mathrm{C} 20$ & Delays between tender and contract award date & 0.60 & & & & \\
\hline $\mathrm{C} 22$ & Requirements of donors in joint funding arrangements & 0.55 & & & & \\
\hline $\mathrm{C} 8$ & $\begin{array}{l}\text { Variations and additional work as a result of changes } \\
\text { in site conditions }\end{array}$ & & 0.66 & & & \multirow{5}{*}{8.54} \\
\hline $\mathrm{C} 11$ & $\begin{array}{l}\text { Arbitrariness in the selection of a margin for price and } \\
\text { physical contingency }\end{array}$ & & 0.71 & & & \\
\hline $\mathrm{C} 12$ & $\begin{array}{l}\text { Excessive use of prime cost and provisional sums in the } \\
\text { Bills of Quantities }\end{array}$ & & 0.72 & & & \\
\hline C19 & $\begin{array}{l}\text { Collusion between consultants/public officials and } \\
\text { contractors }\end{array}$ & & 0.66 & & & \\
\hline $\mathrm{C} 21$ & $\begin{array}{l}\text { Variations and additional works borne out of political } \\
\text { expediency }\end{array}$ & & 0.80 & & & \\
\hline $\mathrm{C} 5$ & $\begin{array}{l}\text { Excessive increases in material and labour prices over } \\
\text { the project duration }\end{array}$ & & & 0.55 & & \multirow{5}{*}{5.10} \\
\hline $\mathrm{C} 7$ & $\begin{array}{l}\text { Poor budget estimation of project cost sent to Ministry } \\
\text { of Finance by implementing agencies }\end{array}$ & & & 0.59 & & \\
\hline C9 & $\begin{array}{l}\text { Poor calibre of contractors reflected in the contractor's } \\
\text { technical staff }\end{array}$ & & & 0.74 & & \\
\hline $\mathrm{C} 15$ & Deficiencies with public procurement & & & 0.71 & & \\
\hline $\mathrm{C} 16$ & $\begin{array}{l}\text { Excessive bribery and cronyism affecting payment for } \\
\text { work done }\end{array}$ & & & 0.61 & & \\
\hline $\mathrm{C} 2$ & $\begin{array}{l}\text { Errors and discrepancies in contract document such as } \\
\text { architectural and structural designs, bills of quantities } \\
\text { and specification }\end{array}$ & & & & 0.72 & \multirow{2}{*}{4.73} \\
\hline C3 & $\begin{array}{l}\text { Lack of coordination and communication during the } \\
\text { design stage between the consultants and the public } \\
\text { procurement entities }\end{array}$ & & & & 0.53 & \\
\hline
\end{tabular}


C4 Lack of enforcement of contract provisions by all parties

C6 Delays and uncertainties surrounding payment of work done

C14 Frequent shortages in materials such as cement and 0.65

Total Variance Explained

F - Factor 